Please do not remove this page

RMIT

UNIVERSITY

\title{
The effect of ultrasonic melt treatment on macro-segregation and peritectic transformation in an Al-19Si-4Fe alloy
}

Todaro, Carmelo; Easton, Mark; Qiu, Dong; Wang, Gui; StJohn, David; Qian, Ma

https://researchrepository.rmit.edu.au/esploro/outputs/9921863310201341/filesAndLinks?institution=61RMIT_INST\&index=null

Todaro, C., Easton, M., Qiu, D., Wang, G., StJohn, D., \& Qian, M. (2017). The effect of ultrasonic melt treatment on macro-segregation and peritectic transformation in an Al-19Si-4Fe alloy. Metallurgical and Materials Transactions A, 48A(11), 5579-5590. https://doi.org/10.1007/s11661-017-4325-1

Document Version: Accepted Manuscript

Published Version: https://doi.org/10.1007/s11661-017-4325-1

Repository homepage: https://researchrepository.rmit.edu.au

(C)The Minerals, Metals and Materials Society and ASM International 2017

Downloaded On 2023/04/26 23:07:30 +1000 
Thank you for downloading this document from the RMIT Research Repository.

The RMIT Research Repository is an open access database showcasing the research outputs of RMIT University researchers.

RMIT Research Repository: http://researchbank.rmit.edu.au/

\section{Citation:}

Todaro, C, Easton, M, Qiu, D, Wang, G, StJohn, D and Qian, M 2017, 'The effect of ultrasonic melt treatment on macro-segregation and peritectic transformation in an Al-19Si-4Fe alloy', Metallurgical and Materials Transactions A, vol. 48, no. 11, pp. 5579-5590.

See this record in the RMIT Research Repository at:

https://researchbank.rmit.edu.au/view/rmit:47967

Version: Accepted Manuscript

Copyright Statement:

(C) The Minerals, Metals and Materials Society and ASM International 2017

\section{Link to Published Version:}

https://dx.doi.org/10.1007/s11661-017-4325-1 


\title{
The effect of ultrasonic melt treatment on macro-segregation and peritectic transformation in an $\mathrm{Al}-19 \mathrm{Si}-4 \mathrm{Fe}$ alloy
}

\author{
C.J. TODARO, M.A. EASTON, D. QIU, G. WANG, D.H. StJOHN and M. QIAN
}

Author information: C.J. TODARO (3286777@student.rmit.edu.au), Ph.D. Candidate, M.A. EASTON (mark.easton@rmit.edu.au) and M. QIAN (ma.qian@rmit.edu.au), Professors, and D. QIU (dong.qiu2@rmit.edu.au), Senior Research Fellow, are with the Centre for Additive Manufacturing, School of Engineering, RMIT University, Melbourne, VIC 3000, Australia. D.H. StJOHN ( (gui.wang@uq.edu.au), Senior Research Fellow, are with the Centre for Advanced Materials Processing and Manufacturing (AMPAM), School of Mechanical and Mining Engineering, The University of Queensland, St Lucia, QLD 4072, Australia. Contact e-mail: ma.qian@rmit.edu.au.

\section{Abstract:}

It is well documented that ultrasonic melt treatment (USMT) can refine dendritic and eutectic microstructures during solidification, but much less attention has been paid to the effect of USMT on macro-segregation and intermetallic transformations. In this research, macrosegregation and primary Fe-containing intermetallic peritectic transformations in an Al-19 wt pct Si-4 wt pet Fe alloy were investigated without and with USMT. Macrostructural examination showed that in the absence of USMT the ingot revealed considerable nonuniform distribution of both the primary Fe-containing intermetallic and primary Si particles, whereas the ingot with USMT exhibited near homogeneous distribution of both primary phases, i.e., reduced macro-segregation. The beneficial effect of USMT on relieving macrosegregation was further examined using quantitative microstructural metallography and the results indicated that the area fraction, number density, and size distribution of both primary phases became essentially uniform across the ingot after USMT. USMT further exerted a significant impact on the constitution of the primary Fe-containing intermetallics, where complex particles of $\delta-\mathrm{Al}_{3} \mathrm{FeSi}_{2} / \beta-\mathrm{Al}_{5} \mathrm{FeSi}$ were prominent without USMT while few $\delta$ $\mathrm{Al}_{3} \mathrm{FeSi}_{2}$ particles were observed after USMT and the primary Fe-containing intermetallics existed mostly as the single-phase $\beta-\mathrm{Al}_{5} \mathrm{FeSi}$. The underlying reason was attributed to the 
reduction in the size of the primary $\delta-\mathrm{Al}_{3} \mathrm{FeSi}_{2}$ particles which ensures the complete transformation of most primary $\delta-\mathrm{Al}_{3} \mathrm{FeSi}_{2}$ particles to the peritectic $\beta-\mathrm{Al}_{5} \mathrm{FeSi}$ phase.

\section{Introduction}

Al-Si based alloys are the most widely used Al-based foundry alloys due to their excellent combination of mechanical properties and ease of castability. Hypoeutectic Al-Si alloys containing 5 to 12 wt pct $\mathrm{Si}$ (wt pct is used hereinafter unless otherwise specified) account for most commercial production. However, hypereutectic Al-Si alloys with 14 to 25 pct Si are more desirable for applications requiring wear resistance, along with high strength and low weight. Transition metal solutes, notably $\mathrm{Fe}, \mathrm{Cr}$, and $\mathrm{Ni}$, in these alloys can further improve their performance at elevated temperatures due to the presence of thermally stable intermetallics [1-2]. The use of $\mathrm{Fe}$ is considered to be particularly attractive for two reasons: it alleviates die soldering for die casting and allows the use of secondary $\mathrm{Al}$ (post-consumer scrap) already containing appreciable amounts of Fe. However, the amount of Fe addition is restricted as the resulting Fe-containing intermetallics can form as large and coarse plateletlike features, deteriorating ductility and fracture toughness [3]. Moreover, it is challenging to obtain microstructurally homogeneous castings of hypereutectic Al-Si based alloys by conventional foundry processes, because of the propensity to form macro-segregation defects during solidification [4]. As a result, special solidification processes such as rapid solidification [5], spray deposition [6], melt thermal-rate treatment (MTRT) [7] and ultrasonic melt treatment (USMT) [8-13] have been employed to control the size, morphology and distribution of Fe-containing intermetallics and primary $\mathrm{Si}$ in hypereutectic Al-Si alloys.

In Fe-containing hypereutectic Al-Si alloys, the Al-Fe-Si phase diagram [14] shows that the following three reactions can occur leading to the formation of $\beta-\mathrm{Al}_{5} \mathrm{FeSi}$ during equilibrium solidification:

(1) $\quad \mathrm{L}+\delta-\mathrm{Al}_{3} \mathrm{FeSi}_{2} \rightarrow \beta-\mathrm{Al}_{5} \mathrm{FeSi}+\mathrm{Si}$

(2) $\quad \mathrm{L} \rightarrow \beta-\mathrm{Al}_{5} \mathrm{FeSi}+\mathrm{Si}$

(3) $\quad \mathrm{L} \rightarrow \alpha-\mathrm{Al}+\mathrm{Si}+\beta-\mathrm{Al}_{5} \mathrm{FeSi}$

During reaction (1), the $\beta-\mathrm{Al}_{5} \mathrm{FeSi}$ phase forms on $\delta-\mathrm{Al}_{3} \mathrm{FeSi}_{2}$ via a quasi-peritectic reaction which occurs only when the Si and Fe contents are greater than 17.7 and 2.8 pct, respectively, by thermodynamic calculations using the software package Pandat ${ }^{\mathrm{TM}}$ and PanAluminium 2016 database. When the Si and Fe solute concentrations are more dilute, however, the $\beta-\mathrm{Al}_{5} \mathrm{FeSi}$ phase can simply form directly from the liquid as a pre-eutectic phase 
according to reaction (2). Finally, some $\beta-\mathrm{Al}_{5} \mathrm{FeSi}$ phase can form as a component of the $\alpha$-Al $+\mathrm{Si}+\beta-\mathrm{Al}_{5} \mathrm{FeSi}$ ternary eutectic by reaction (3). Nonetheless, the phase $\delta-\mathrm{Al}_{3} \mathrm{FeSi}_{2}$ has been reported to also exist in dilute Al-Fe-Si alloys [15], highlighting the complexity of the Al-FeSi system. Furthermore, peritectic $\beta-\mathrm{Al}_{5} \mathrm{FeSi}$ often coexists with the primary $\delta-\mathrm{Al}_{3} \mathrm{FeSi}_{2}$ phase in the as-cast microstructure, because the peritectic transformation of $\delta$ - $\mathrm{Al}_{3} \mathrm{FeSi}_{2}$ into $\beta$ $\mathrm{Al}_{5} \mathrm{FeSi}$ in reaction (1) rarely goes to completion. Two studies have investigated quasiperitectic reactions in the Al-Fe-Si system [16-17], but they both dealt with low $\mathrm{Fe}$ hypoeutectic Al-Si alloys. Hence, there is a lack of understanding of the solidification reactions that occur in hypereutectic $\mathrm{Al}-\mathrm{Si}$ alloys containing moderate additions of $\mathrm{Fe}$ and the growth mechanisms involved.

USMT has been employed in solidification processing to control the nucleation and growth of primary crystalline phases, together with the macro- and microstructural features in castings [18-26]. Hence, the use of USMT has attracted attention for refining the size and modifying the morphology of Fe-containing intermetallics [8, 27] and primary Si [28-30], including when both phases coexist in hypereutectic Al-Si alloys [8-13]. Table I summarises the studies on USMT of hypereutectic Al-Si alloys containing deliberate additions of Fe. However, in these reports, inadequate information was provided on the experimental parameters, such as the ultrasonic horn diameter, ultrasonic amplitude and horn pre-heating temperature, which makes it difficult to compare the results. Furthermore, very different melt temperatures or superheats were used (Table I), which are known to have an important effect on the microstructure, e.g., the use of a lower melt temperature tends to produce a finer grain structure [31]. Therefore, it is important to isolate the effect of the melt temperature from that of USMT.

Previous studies [9, 12] have shown that USMT suppresses the formation of the peritectic $\beta$-phase in hypereutectic Al-Si based alloys, but leads to the formation of the primary $\delta$-phase instead. This implies that USMT can stifle the peritectic transformation $\delta$ $\mathrm{Al}_{3} \mathrm{FeSi}_{2} \rightarrow \beta-\mathrm{Al}_{5} \mathrm{FeSi}$. However, contrasting results have also been reported on other alloy systems such as $\mathrm{Sb}-\mathrm{Sn}$ [32], $\mathrm{Cu}-\mathrm{Sn}$ [33] and Ti-Al [34], in which peritectic transformations were clearly promoted by USMT. This difference demands an in-depth investigation into the role of USMT on the peritectic transformation of primary Fe-containing intermetallics in hypereutectic Al-Si alloys. Additionally, although USMT has been shown to be effective in mitigating separation in immiscible Al-Sn-Cu alloys [35-36], no systematic study has been presented yet on the effect of USMT on macro-segregation in conventional Al alloys. 
In view of this, this study was carried out to evaluate the macro-segregation and the formation of Fe-containing intermetallics in a slowly cooled Al-19Si-4Fe alloy without and with USMT. The ternary alloying addition of 4 pct Fe was selected because (i) it ensures the occurrence of the quasi-peritectic reaction $\mathrm{L}+\delta-\mathrm{Al}_{3} \mathrm{FeSi}_{2} \rightarrow \beta-\mathrm{Al}_{5} \mathrm{FeSi}+\mathrm{Si}$; (ii) it produces a sufficient volume fraction of intermetallic phases facilitating microscopic investigation; and, (iii) it is comparable to the additions of Fe in previous studies (see Table I).

\section{Experimental procedures}

\section{A. Materials}

The Al-19Si-4Fe alloy was produced by melting commercially pure Al (99.7 pct), Si (99.5 pct) and an $\mathrm{Al}-10 \mathrm{Fe}$ master alloy at $1073 \mathrm{~K}\left(800{ }^{\circ} \mathrm{C}\right)$ in an induction furnace and held for 10 mins before casting into boron nitride-coated steel moulds to produce $350 \mathrm{~g}$ ingot charges. A single ingot charge was then placed in a boron nitride-coated clay-graphite crucible (90 $\mathrm{mm}$ top outer diameter, $55 \mathrm{~mm}$ bottom outer diameter and $92 \mathrm{~mm}$ in height) and remelted and held in a resistance furnace at $1073 \mathrm{~K}\left(800^{\circ} \mathrm{C}\right)$ for $30 \mathrm{~min}$. The liquid alloy was stirred for $1 \mathrm{~min}$ for complete and homogeneous dissolution and then furnace-cooled. The melt temperature was recorded with a frequency of 10 readings per second by a K-type thermocouple located approximately one-half radius from the inner crucible wall. The first derivative cooling curves were mathematically smoothed using the adjacent-average method over 25 data points (no further smoothing was applied). The cooling rate prior to primary phase formation was $\sim 0.15 \mathrm{~K} \mathrm{~s}^{-1}$.

\section{B. USMT procedure}

Fig. 1 displays the USMT set-up. The commercial ultrasonic system is comprised of a $500 \mathrm{~W}$ generator, a fan-cooled $20 \mathrm{kHz}$ half wavelength piezoelectric sandwich transducer and a $25 \mathrm{~mm}$ diameter tip acoustic sonotrode made from Ti-6Al-4V alloy. The maximum vibration amplitude at the sonotrode working face is $12 \pm 1 \mu \mathrm{m}$ peak to peak. The sonotrode was immersed into the melt to a depth of $10 \mathrm{~mm}$ at $973 \mathrm{~K}\left(700{ }^{\circ} \mathrm{C}\right)$ with the ultrasonic system switched on prior to immersion. The sonotrode was preheated to $773 \mathrm{~K}\left(500{ }^{\circ} \mathrm{C}\right)$ before it was immersed into the melt to alleviate the tendency for a solidified layer to form on the sonotrode working face. It was removed from the melt at $883 \mathrm{~K}\left(610^{\circ} \mathrm{C}\right)$. 


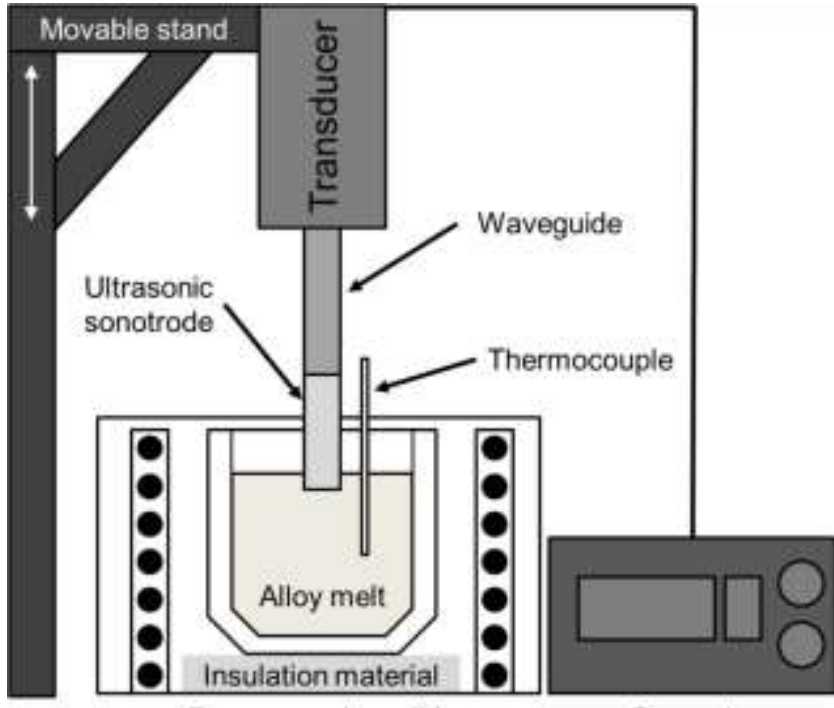

Fig. 1-Schematic illustration of the experimental set-up.

The ultrasonic intensity, $I$, required to overcome the cavitation threshold in typical $\mathrm{Al}$ melts has been determined to be $I \geq 100 \mathrm{~W} \mathrm{~cm}^{-2}$ [19], where $I$ is defined by [19]: $I=1 / 2 \rho c(2 \pi f A)^{2}$ where $\rho$ is the liquid mass density, $c$ is the speed of sound in the liquid, $f$ is the frequency and $A$ is the amplitude of the ultrasound. The density of $\mathrm{Al}$ at $973 \mathrm{~K}\left(700{ }^{\circ} \mathrm{C}\right)$ (i.e., the USMT start temperature) is $2375 \mathrm{~kg} \mathrm{~m}^{-3}$ [37], which increases to $2395 \mathrm{~kg} \mathrm{~m}^{-3}$ when alloyed with 19 pct $\mathrm{Si}$ and 4 pct Fe [14]. The speed of sound in the alloy used is assumed to be that of a simple Al-19 pct Si binary alloy which at $973 \mathrm{~K}\left(700{ }^{\circ} \mathrm{C}\right)$ has been reported to be $4573 \mathrm{~m} \mathrm{~s}^{-1}$ [38]. The ultrasonic intensity at the sonotrode working face-melt interface can be estimated to be $1245 \mathrm{~W} \mathrm{~cm}^{-2}$ using Eq. [1], which is over an order of magnitude greater than the ultrasonic intensity threshold $\left(100 \mathrm{~W} \mathrm{~cm}^{-2}\right)$ required for the formation of a cavitation zone.

\section{Characterisation}

As-solidified ingot samples were sectioned longitudinally for metallographic observations. The half castings were cut into small pieces, each with a section area of $10 \mathrm{~mm}$ $\times 10 \mathrm{~mm}$ at four different positions on the cross section, representing the top surface, central, bottom and side wall regions of the casting, as shown in Fig. 3. The samples were mounted, ground and polished, using standard metallographic techniques.

The morphology and composition of phases were examined with an FEI NanoSEM scanning electron microscope (SEM) in the backscattered electron (BSE) mode, equipped with an Oxford Instruments X-MaxN 20 energy dispersive X-ray spectroscopy (EDS) 
detector. Image analysis software package ImageJ was used to investigate and measure various microstructural parameters of the different phase constituents from the backscattered images. At least 15 fields of view were analysed for each zone, where each field covered an area of $2.64 \mathrm{~mm}^{2}$.

\section{Results}

\section{A. The effect of USMT on cooling curves}

The Lever rule module of Pandat ${ }^{\mathrm{TM}}$ [39] with the PanAluminium 2016 database was used for solidification simulation of the Al-19Si-4Fe alloy. Fig. 2 presents the temperature $v s$ fraction solid of the alloy, in which the following series of reactions take place:
(1) $\quad \mathrm{L} \rightarrow \delta-\mathrm{Al}_{3} \mathrm{FeSi}_{2}$
$937 \mathrm{~K}\left(664^{\circ} \mathrm{C}\right)$
(2) $\mathrm{L} \rightarrow \delta-\mathrm{Al}_{3} \mathrm{FeSi}_{2}+\mathrm{Si}$
$927 \mathrm{~K}\left(654^{\circ} \mathrm{C}\right)$
(3) $\mathrm{L}+\delta-\mathrm{Al}_{3} \mathrm{FeSi}_{2} \rightarrow \beta-\mathrm{Al}_{5} \mathrm{FeSi}+\mathrm{Si}$
$914 \mathrm{~K}\left(641^{\circ} \mathrm{C}\right)$
(4) $\mathrm{L} \rightarrow \alpha-\mathrm{Al}+\mathrm{Si}+\beta-\mathrm{Al}_{5} \mathrm{FeSi}$
$848 \mathrm{~K}\left(575^{\circ} \mathrm{C}\right)$

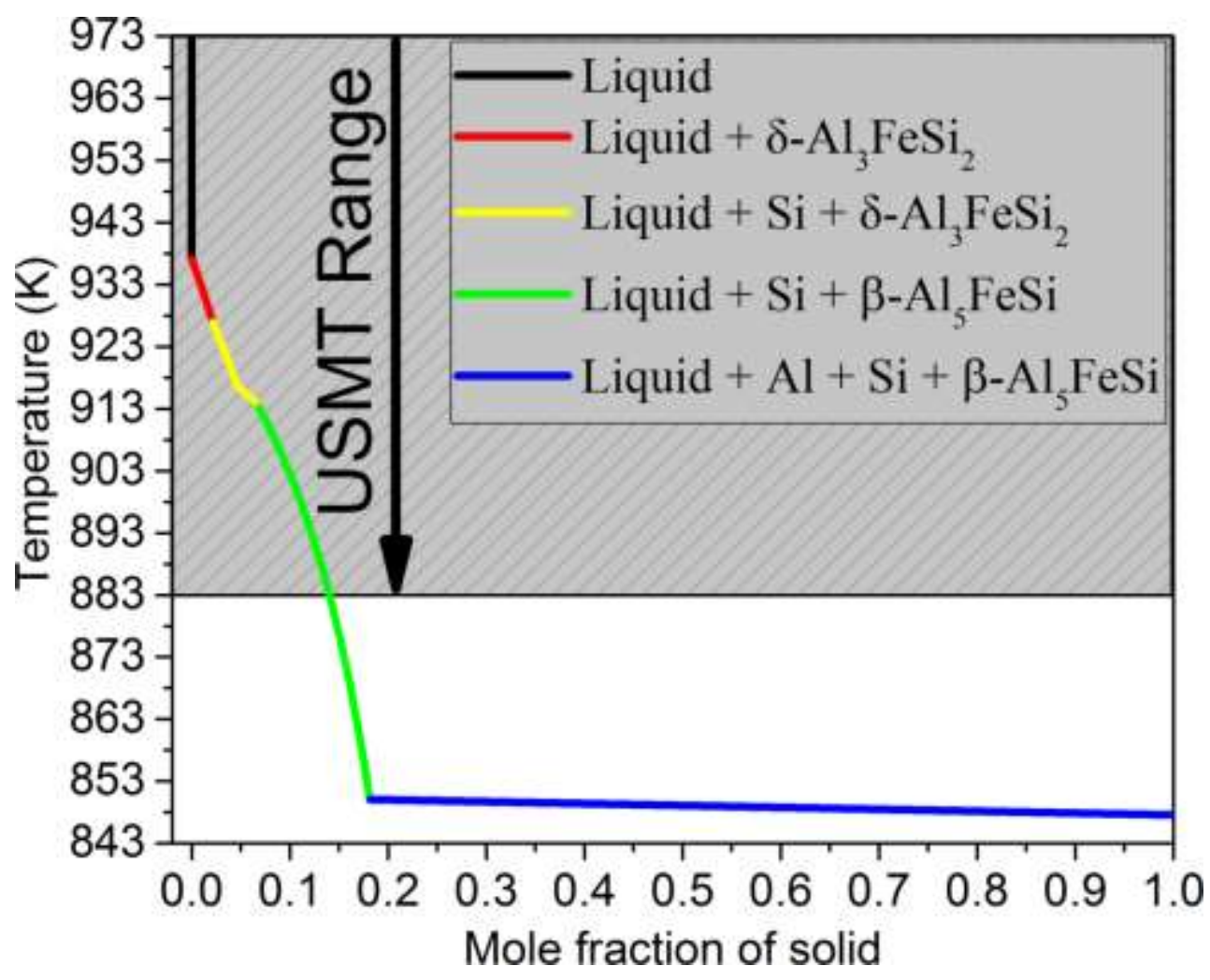

Fig. 2-Temperature $v s$ fraction solid curve as predicted by PANDAT $^{\mathrm{TM}}$ assuming equilibrium solidification of the Al-19Si-4Fe alloy. 
Fig 3(a, b) shows the cooling curves and their first derivatives obtained for the alloy without and with USMT. The reaction temperatures were determined from the first derivative [40]. Based on Fig. 2, the reaction and corresponding temperatures are listed in Table II.

Solidification of the alloy without USMT starts at $938 \mathrm{~K}\left(665^{\circ} \mathrm{C}\right)$, corresponding to the precipitation of $\delta-\mathrm{Al}_{3} \mathrm{FeSi}_{2}$ (marked 1 in the figure). A second reaction overlaps considerably with the first one given the small temperature difference between these two reactions. Nonetheless, primary Si precipitation occurs at $936 \mathrm{~K}\left(663{ }^{\circ} \mathrm{C}\right)$ (marked 2). The peritectic reaction $\mathrm{L}+\delta-\mathrm{Al}_{3} \mathrm{FeSi}_{2} \rightarrow \beta-\mathrm{Al}_{5} \mathrm{FeSi}+\mathrm{Si}$ takes place at $868 \mathrm{~K}\left(595{ }^{\circ} \mathrm{C}\right)($ marked 3). Lastly, the main ternary eutectic reaction $\mathrm{L} \rightarrow \alpha-\mathrm{Al}+\mathrm{Si}+\beta-\mathrm{Al}_{5} \mathrm{FeSi}$ occurs at $849 \mathrm{~K}(576$ ${ }^{\circ} \mathrm{C}$ ) (marked 4). These experimentally determined reaction temperatures are consistent with the thermodynamic predictions, except for the peritectic reaction (3) where the difference between the values is $46 \mathrm{~K}$. Meanwhile, the experimentally observed peritectic reaction temperature of $868 \mathrm{~K}\left(595^{\circ} \mathrm{C}\right)$ is consistent with literature data, such as $868 \mathrm{~K}\left(595^{\circ} \mathrm{C}\right)$ [41] and $869 \mathrm{~K}\left(596^{\circ} \mathrm{C}\right)[42]$.

For the alloy with USMT, the insertion of the sonotrode at $927 \mathrm{~K}\left(700{ }^{\circ} \mathrm{C}\right)$ led to a sudden drop in melt temperature of about $12 \mathrm{~K}$, followed by a decrease in cooling rate to a relatively stable rate of $\sim 0.06 \mathrm{~K} \mathrm{~s}^{-1}$. The sonotrode itself increases the heat extraction rate rapidly, until the point where the temperature of the sonotrode reaches thermal equilibration with the melt and the cooling rate stabilises afterwards. During USMT there was much more noise in the temperature signal. This is likely related to the cavitation and acoustic streaming effects in the region of the thermocouple tip. As a result, the reaction arrest temperatures for the precipitation of primary $\delta-\mathrm{Al}_{3} \mathrm{FeSi}_{2}$ and primary $\mathrm{Si}$ are difficult to determine. Upon removing the sonotrode at $883 \mathrm{~K}\left(610^{\circ} \mathrm{C}\right)$, a sudden increase in the cooling rate occurs to a stable rate of $\sim 0.16 \mathrm{~K} \mathrm{~s}^{-1}$. The acoustic energy introduced into the melt can effectively lead to a slower cooling rate during treatment [19]. Finally the peritectic (marked 3) and ternary eutectic (marked 4) reactions occur at $868 \mathrm{~K}\left(595{ }^{\circ} \mathrm{C}\right)$ and $849 \mathrm{~K}\left(576{ }^{\circ} \mathrm{C}\right)$, which are the same temperatures as without USMT. 

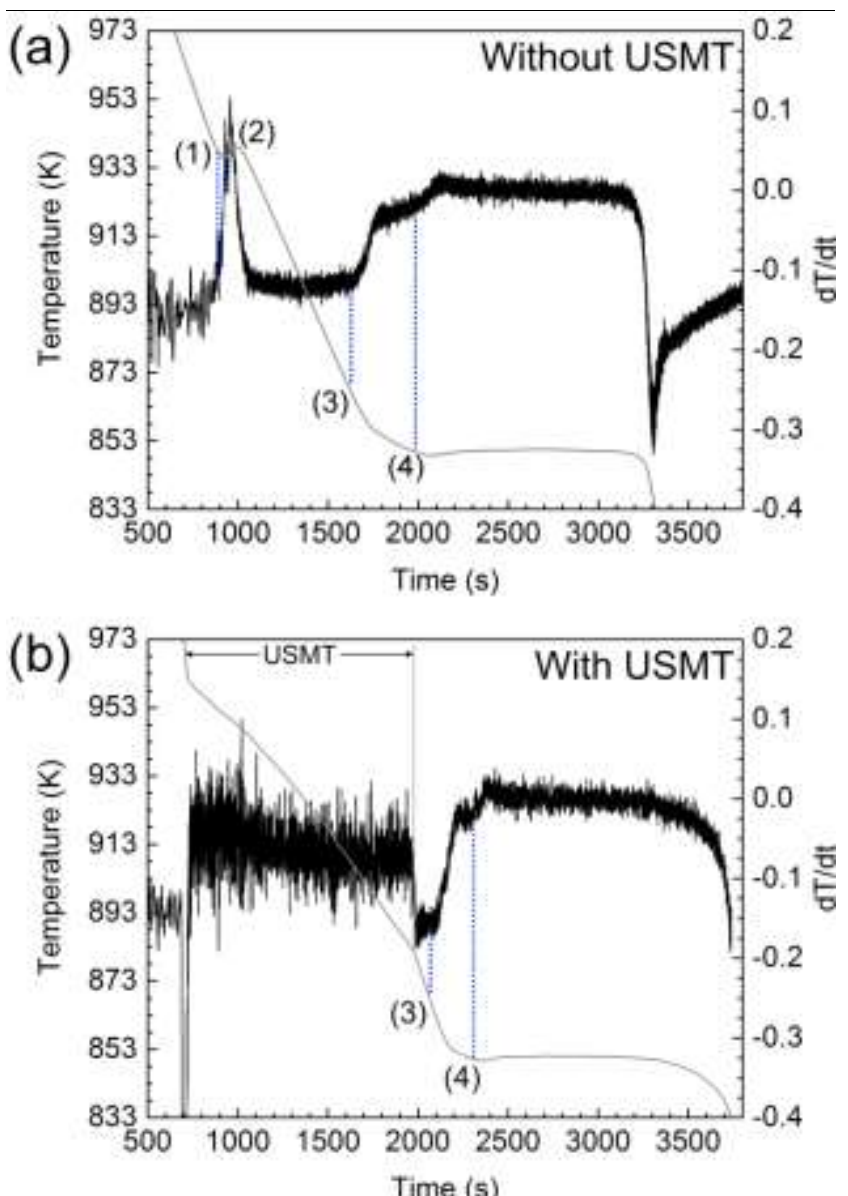

203 Fig. 3-Cooling curves and their first derivatives for the Al-19Si-4Fe alloy: (a) without 204 USMT and (b) with USMT.

\section{B. The effect of USMT on the macrostructure}

Fig. 4 (a, b) presents optical macrographs of the vertical sections of the alloy without and with USMT. In the absence of USMT, primary Fe-containing intermetallics and primary $\mathrm{Si}$ are concentrated near the top surface (Zone I in Fig. 4a) as well as the bottom and side walls of the crucible (Zones III and IV in Fig. 4a). No primary particles are visible in the central region (Zone II), which covers about 60 vol. pct of the ingot. Additionally, large 212 shrinkage cavities appear in the central region. With USMT, these cavities are essentially 213 eliminated, and, at least from a macroscopic point of view, fine Fe-containing intermetallics and primary Si particles are uniformly distributed throughout the ingot. 

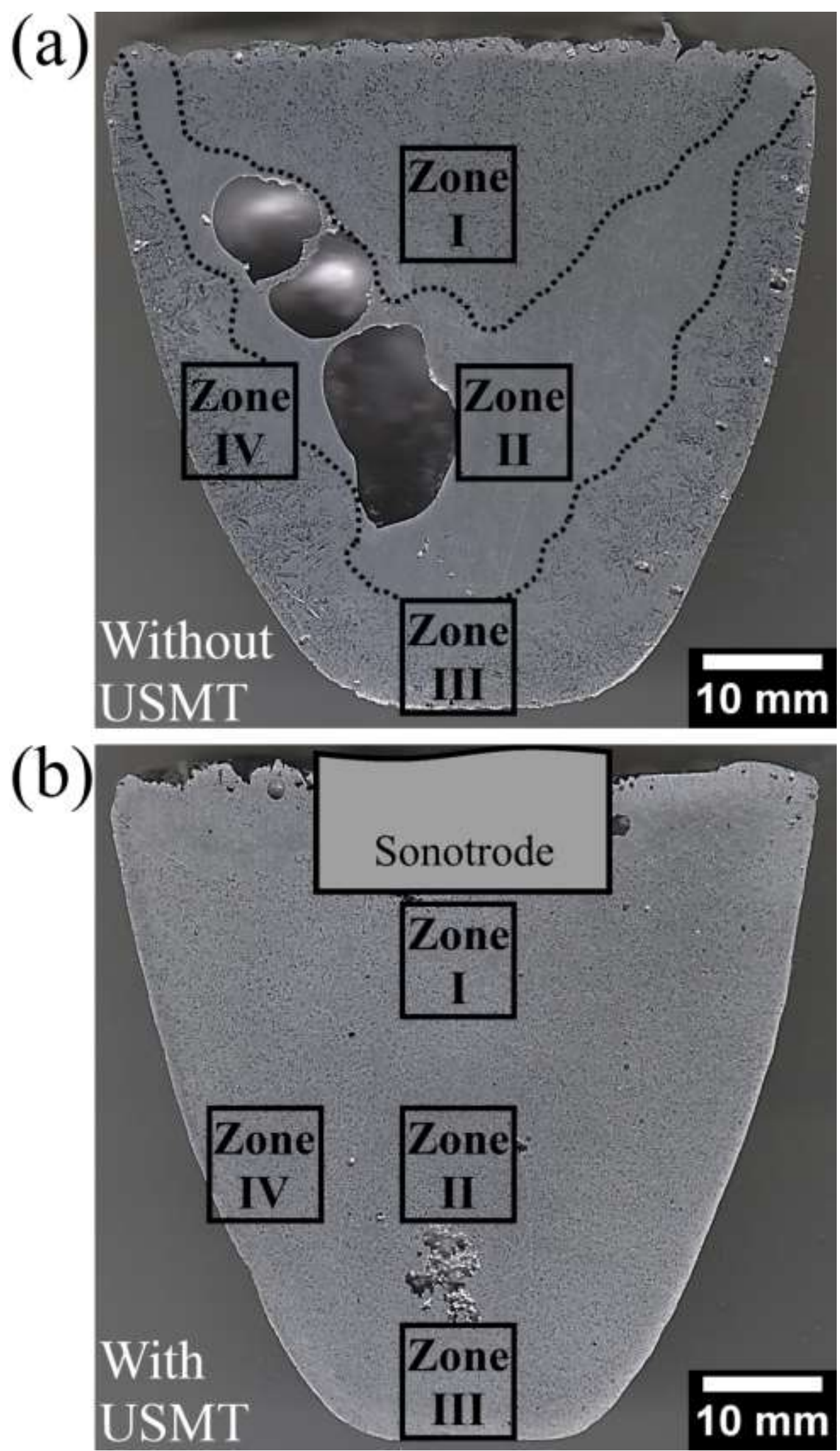
217 Fig. 4-(a) Vertical section of a solidified Al-19Si-4Fe ingot without USMT and (b) the 218 same alloy with USMT. Note the distinct difference in macro-segregation and phase 219 distribution in (a) and (b).

\section{The effect of USMT on microstructure}

Fig. 5 shows the morphologies of primary Fe-containing intermetallics (white) and primary Si (grey) revealed by SEM BSE images in different regions of the ingot samples

224 solidified without and with USMT. The main features can be summarised as follows: (i) the long platelet-like primary Fe-containing intermetallics observed in Zone I of the ingot without USMT disappeared after USMT; (ii), After USMT, the morphology of the primary

227 Fe-containing intermetallics and primary $\mathrm{Si}$ particles are observed to be finer and more 228 homogeneous compared to without USMT and display approximately rod-like and polyhedral 229 morphologies, respectively; (iii) both the primary phase particles are well distributed across 230 all zones of the ingot with USMT, as opposed the non-uniform microstructure of the ingot without USMT where primary phase particles are evident near the melt surface and wall regions but are absent in the central region. 


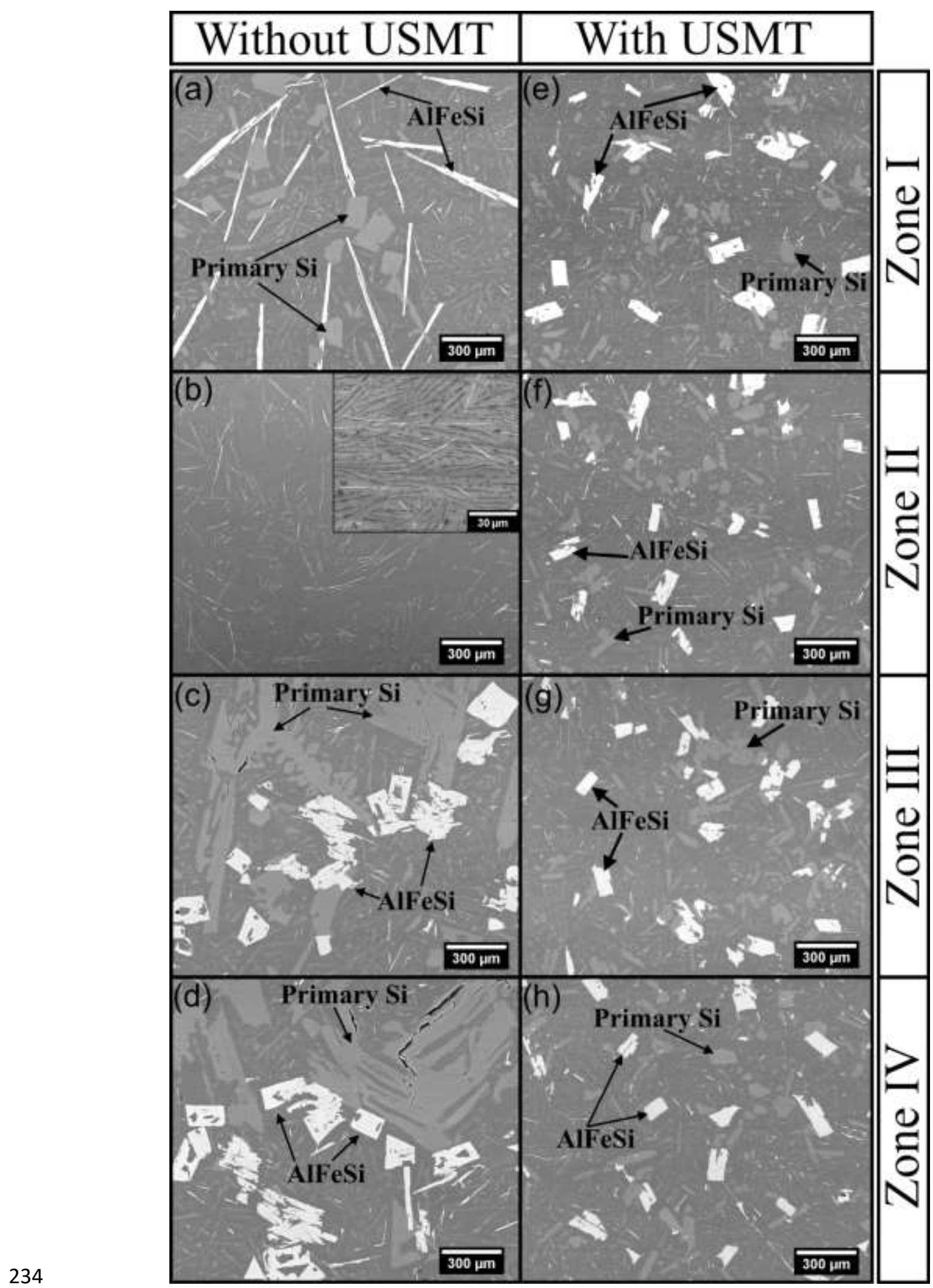

235 Fig. 5-SEM BSE micrographs showing the typical primary phase structures in the four

236 different zones of the Al-19Si-4Fe ingots shown in Fig. 4. 
Area fraction provides a useful measure of the distribution of each primary phase in the ingot. Fig. $6(a, b)$ shows the area fractions of the primary Fe-containing intermetallic and 241 primary Si phases in different regions of the ingots without and with USMT. USMT resulted 242 in both the primary Fe-containing intermetallic and primary Si crystals to be distributed 243 essentially uniformly across the ingot compared to noticeable variations, i.e., macro244 segregation, in the absence of USMT.

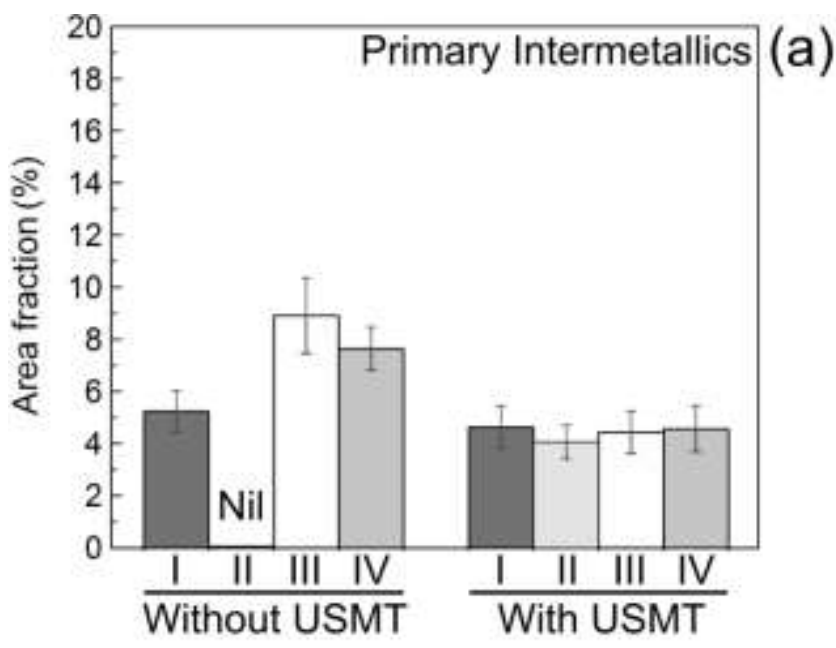

247 Fig. 6-Area fraction of primary phases without and with USMT in the ingot samples shown

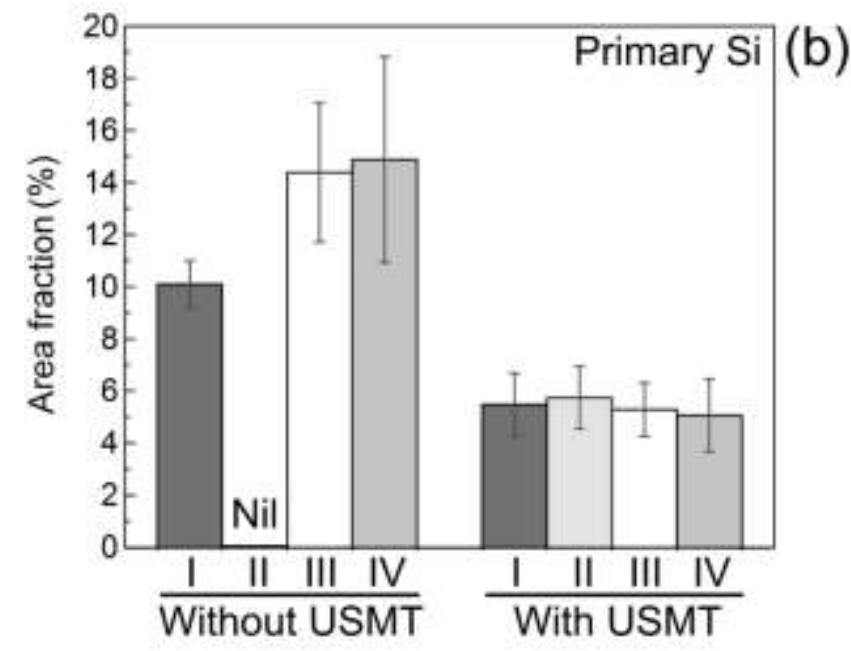
in Fig. 4: (a) primary Fe-containing intermetallics, and (b) primary Si. Refer to Fig. 4 for the different zones.

The number density per unit area of each primary phase in the ingot samples is shown in Fig. 7 (a, b). An appreciable increase in number density was observed after USMT for both the primary Fe-containing intermetallics and primary $\mathrm{Si}$ in each region concerned. Equally 
important is that the number density distribution in the ingot after USMT is far more uniform across all zones of the ingot than in the absence of USMT.

256

257

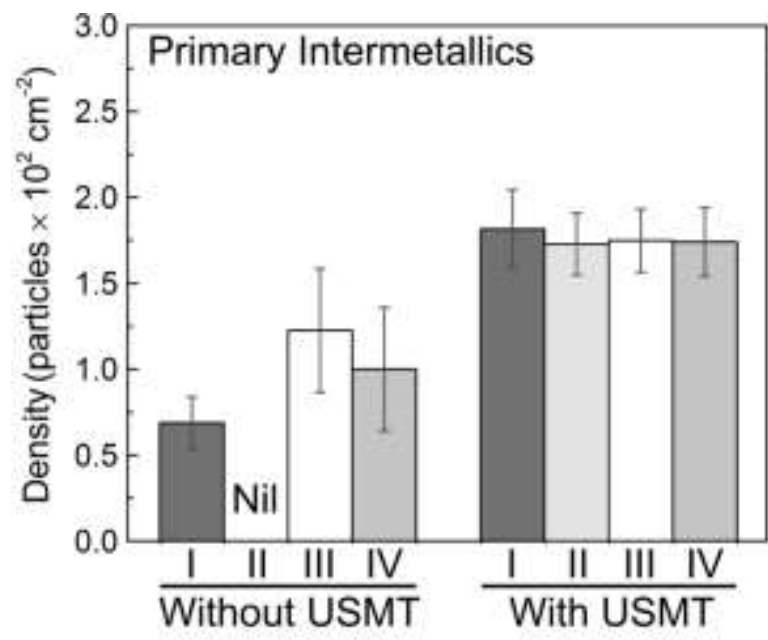

(a)

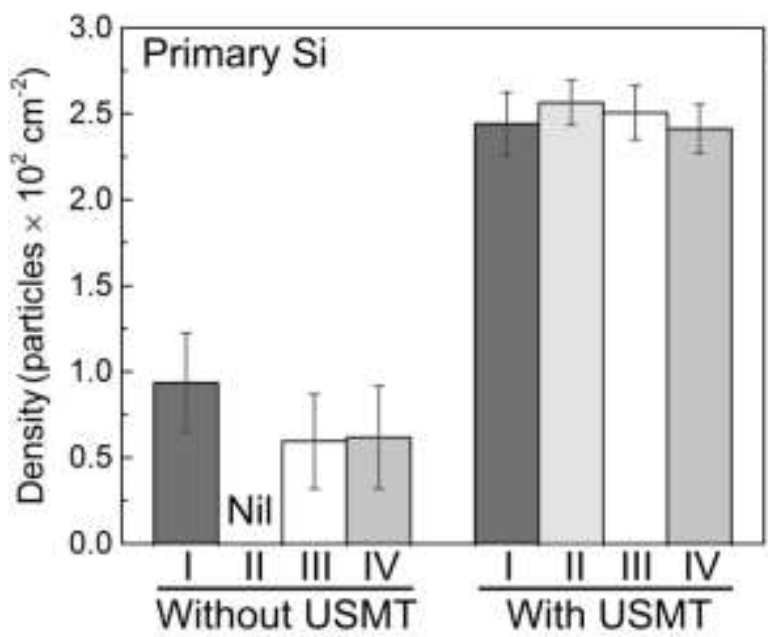

(b)

Fig. 7-Number density of primary phases without and with USMT for the ingot samples shown in Fig. 4: (a) primary Fe-containing intermetallics, and (b) primary Si. Refer to Fig. 4 for the different zones.

261

Along with significant changes in distribution are modified shapes of each primary 263 phase. Fig. 8 (a-d) shows the measured morphological parameters of each primary phase 264 from different regions of the ingot samples shown in Fig. 4. USMT entailed a marked reduction in both the length and width of each primary phase. Also, the size is more homogeneous throughout the ingot after USMT while the difference in size is considerable without USMT. 


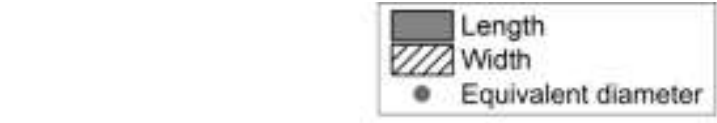

(a)

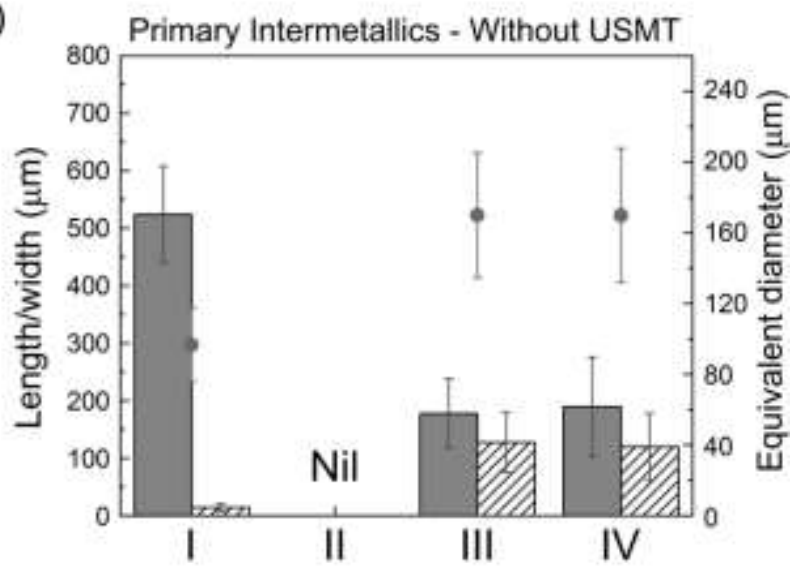

(b)

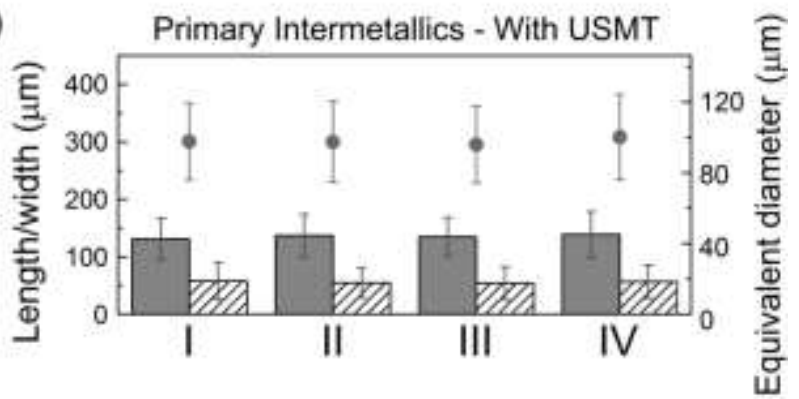

(c)

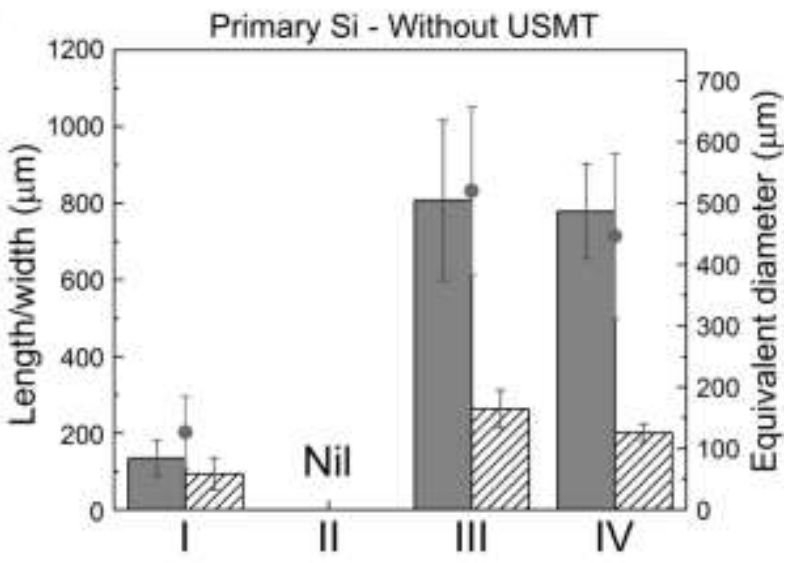

(d)

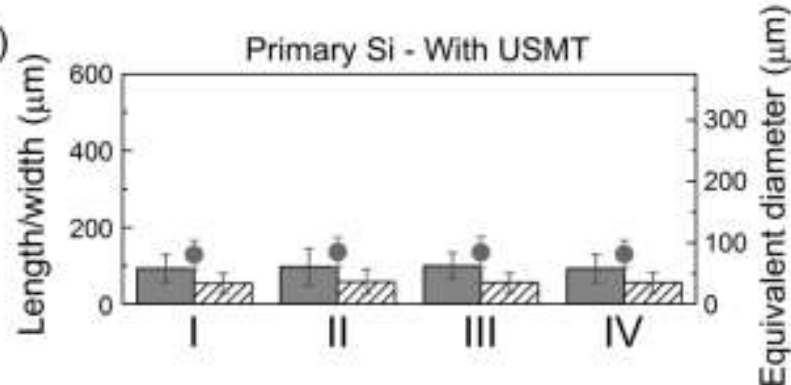

270 Fig. 8-Morphological parameters of primary phases for the alloy ingots shown in Fig. 4: (a) 271 primary Fe-containing intermetallics without USMT; (b) primary Fe-containing intermetallics 
with USMT; (c) primary Si without USMT; and (d) primary Si with USMT. Refer to Fig. 4 for the different zones.

\section{E. Complex particles of $\delta-\mathrm{Al}_{3} \mathrm{FeSi}_{2} / \mathbf{\beta}-\mathrm{Al}_{5} \mathrm{FeSi}$}

A closer inspection of the backscattered micrographs revealed that many of the

277 primary Fe-containing intermetallics existed in a complex form which contained a central

278 lighter phase enveloped by a darker phase in the ingot sample solidified without USMT. In

279 contrast, such particles were observed only occasionally in the ingot sample solidified with

280 USMT. In fact, the vast majority of the primary Fe-containing intermetallic particles in the ingot sample after USMT appeared as single-phase particles.

Fig. 9 shows a representative BSE image of two coarse platelet-like complex primary Fe-containing intermetallic particles observed in Zone I of the ingot sample solidified without USMT. The faint difference in contrast can easily mask the two different intermetallic phases at low magnifications. Fig. 10 (a-c) shows typical blocky complex primary Fe-containing intermetallic particles observed near the wall of the ingot sample without USMT. The relative volume fraction of each phase in the complex particle varies but in all of the complex particles observed the central lighter contrast intermetallic phase showed a large area fraction. For comparison, Fig. 10 (d, e) shows two examples of the single-phase Fe-containing intermetallic particles that are predominant in the ingot sample after USMT. Only a few complex particles were encountered in the ingot sample after USMT. A useful feature to note is that the central lighter contrast intermetallic phase is much smaller than those observed in the case without USMT. Fig. 10 (f) shows one such example. It would appear that the central particle is the remnant of a larger particle formed at the beginning of solidification. 


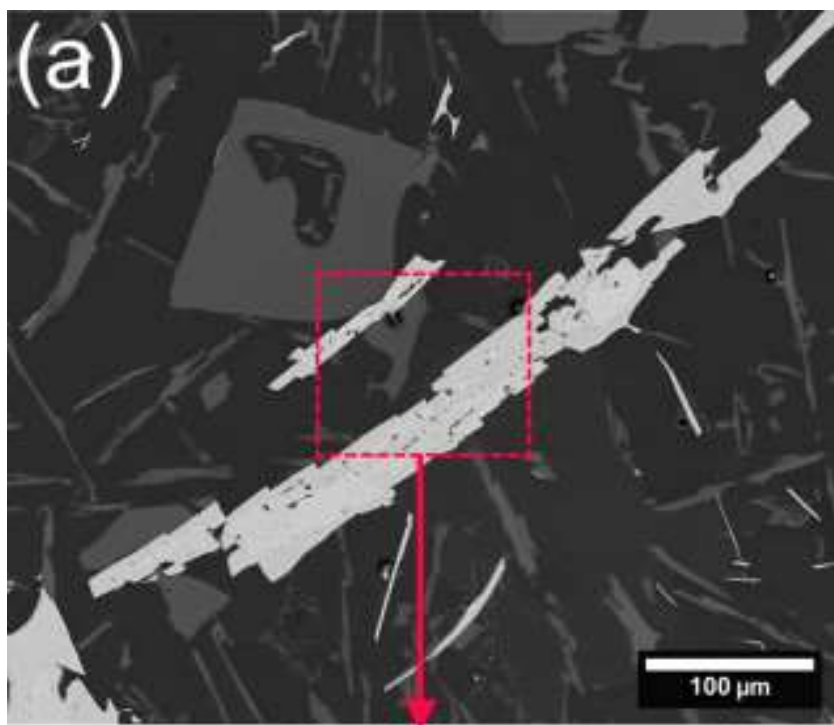

297 Fig. 9-(a) Typical BSE image showing unreacted platelet-like Fe-containing intermetallics 298 existing as complex particles of $\delta-\mathrm{Al}_{3} \mathrm{FeSi}_{2} / \beta-\mathrm{Al}_{5} \mathrm{FeSi}$ in Zone I of the ingot sample solidified 299 without USMT, and (b) an enlarged view. 

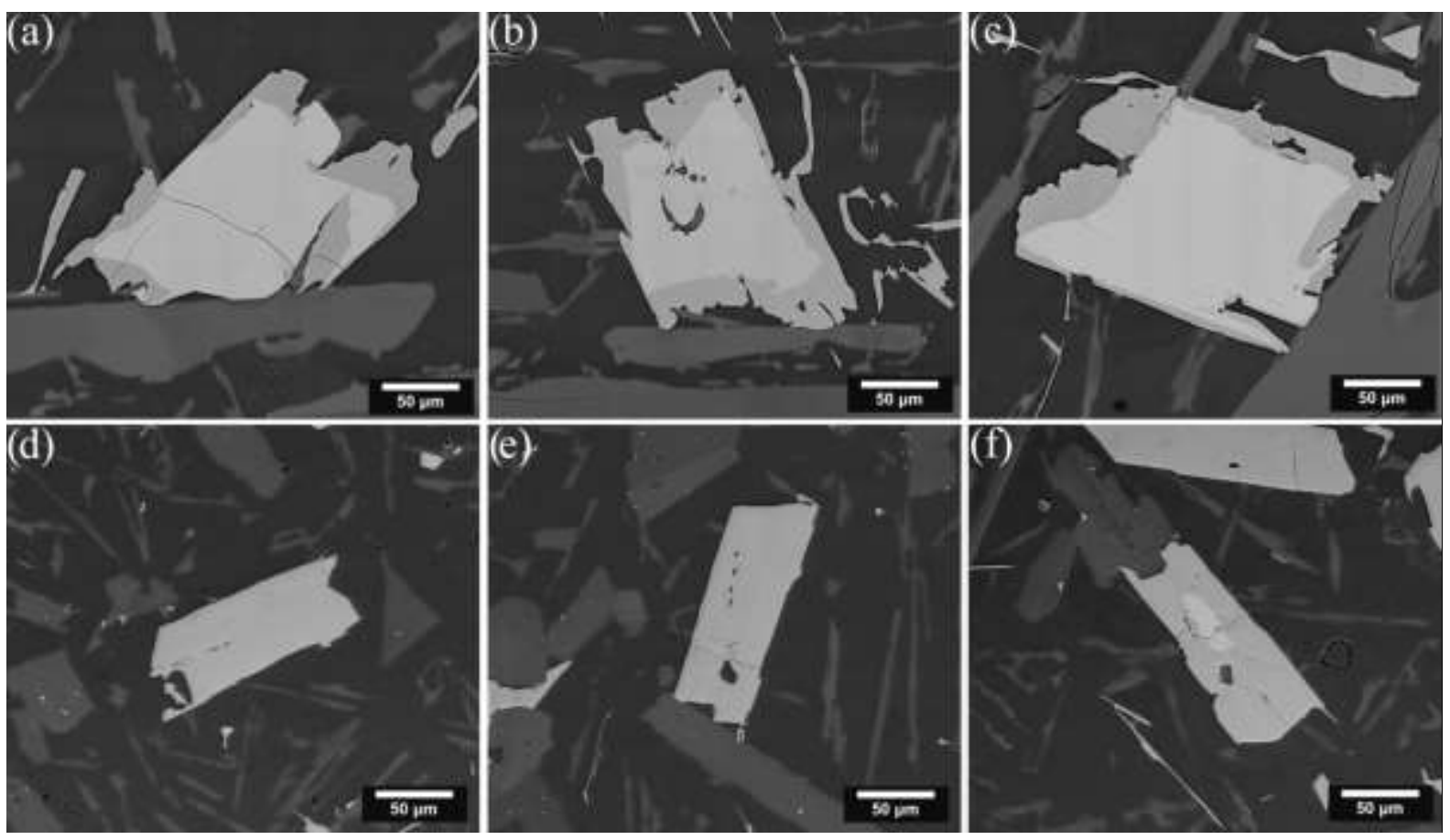

Fig. 10-BSE images showing examples of primary Fe-containing intermetallic particles: (a-

c) complex blocky particles of $\delta-\mathrm{Al}_{3} \mathrm{FeSi}_{2} / \beta-\mathrm{Al}_{5} \mathrm{FeSi}$ observed near the mould wall regions of the ingot samples solidified without USMT; (d, e) single-phase short intermetallic particles observed in the ingot after USMT; and (f) a complex particle of $\delta-\mathrm{Al}_{3} \mathrm{FeSi}_{2} / \beta-\mathrm{Al}_{5} \mathrm{FeSi}$ observed in the ingot sample with USMT.

EDS line scan analyses along the cross section of each selected intermetallic particle from Fig. 10 are shown in Fig. 11. The results confirm that the contrasting phases in the complex particles are not artefacts. Instead, the central phase contained more Si than the outer phase (Fig. $11(\mathrm{a}, \mathrm{b})$ ). The single-phase particles shown in Fig. 10 (f) do not contain an inner Si-rich phase (Fig. 11 (c)). A comprehensive quantitative survey of the chemical compositions of a total of 93 complex and single-phase intermetallic particles was undertaken, and the results are summarised in Table III. Based on these results, the stoichiometry of the central Si-enriched phase is consistent with $\delta-\mathrm{Al}_{3} \mathrm{FeSi}_{2}$, while the outer phase corresponds to $\beta-\mathrm{Al}_{5} \mathrm{FeSi}$. The stoichiometry of the single-phase short rod particles is consistent with $\beta-\mathrm{Al}_{5} \mathrm{FeSi}$. 

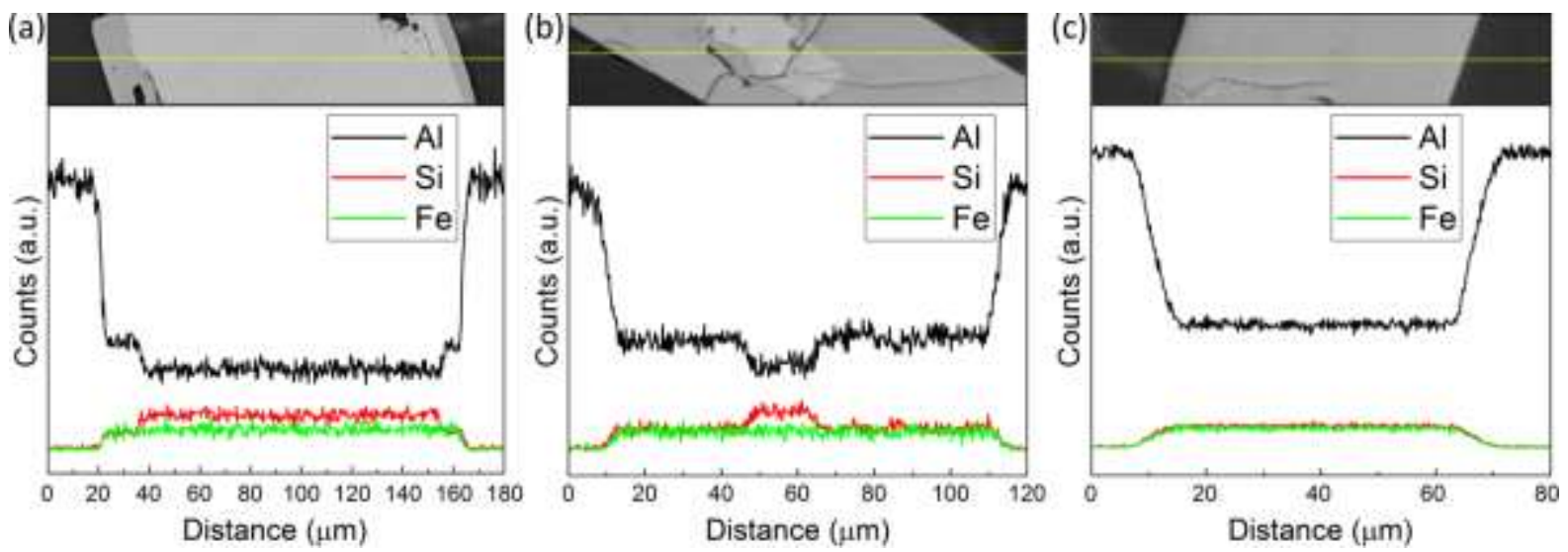

Fig. 11-EDS line scans across selected Fe-containing intermetallics particles: (a) the complex particle in Fig. 9 (c); (b) the complex particle in Fig. 9 (f); and (c) the single-phase $\beta-\mathrm{Al}_{5} \mathrm{FeSi}$ particle in Fig. 9 (e).

\section{Discussion}

\section{A. The effect of USMT on macro-segregation}

The occurrence of macro-segregation of primary Fe-containing intermetallics and primary Si was not unexpected based on previous studies [43-44]. The main mechanisms for the macro-segregation of primary $\mathrm{Si}$ particles have been identified as including [32]: (i) flotation of primary Si particles towards the top of the melt; (ii) heterogeneous nucleation of primary Si on the mould wall; and (iii) localised enhanced growth of primary Si particles. As regards the macro-segregation of primary Fe-containing intermetallics in Al-alloys, they are observed to frequently settle to the bottom of the mould due to gravity leaving the upper part of the casting or ingot depleted of intermetallics [44]. It has also been proposed that some Fecontaining intermetallics may not settle but instead "hang" near both the side mould wall and the top melt surface regions [44]. One possible reason is due to heterogeneous nucleation of primary Fe-containing intermetallics on oxide films or the mould wall, which can effectively slow down or even prevent their sedimentation. This hypothesis can help to explain the macro-segregation of primary phase particles observed near the top melt surface and wall regions, and also their depletion in the central region of the casting. Nonetheless, the mechanisms remain incompletely identified.

USMT produced a uniform distribution of both primary Fe-containing intermetallics and primary $\mathrm{Si}$ (Fig. 6) and eliminated macro-segregation. In addition, it increased the number of each primary phase (Fig. 7) with a uniform size distribution (Fig. 8). The high potency of USMT in dispersing the primary Fe-containing intermetallics and primary Si can be attributed to the combined effects of the enhanced heterogeneous nucleation of each 
primary phase (cavitation-induced, including fragmentation) and dynamic solidification environment (acoustic streaming and cavitation) created by ultrasonic waves. Both effects of USMT have long been recognised and discussed in the literature [18-23, 45]. They will not be restated herein. One additional benefit of the cavitation effect of USMT is that it produces an essentially thoroughly mixed effect thereby preventing large primary phase particles from quickly sinking or floating. As a result, gravity segregation of the primary phase particles is mitigated. This ability of USMT to fully eliminate macro-segregation so efficiently has not been well demonstrated previously to the authors' best knowledge and it was not totally expected prior to this research. In that regard, this research extends perspectives on the capabilities of USMT.

\section{B. The effect of USMT on peritectic transformation of intermetallics}

The thermodynamic calculation shown in Fig. 2 predicts that an invariant quasiperitectic reaction $\mathrm{L}+\delta-\mathrm{Al}_{3} \mathrm{FeSi}_{2} \rightarrow \beta-\mathrm{Al}_{5} \mathrm{FeSi}+\mathrm{Si}$ occurs during solidification of the Al19Si-4Fe alloy. As proposed by Sha et al. [17], the study of quasi-peritectic reactions can be based on the normal peritectic reaction theory [46-52]. On this basis, the quasi-peritectic formation of $\beta-\mathrm{Al}_{5} \mathrm{FeSi}$ can be regarded as consisting of two stages: (i) the normal peritectic reaction, during which direct reaction between $\delta-\mathrm{Al}_{3} \mathrm{FeSi}_{2}$ and liquid leads to the formation of a continuous envelope of $\beta-\mathrm{Al}_{5} \mathrm{FeSi}$ surrounding each $\delta-\mathrm{Al}_{3} \mathrm{FeSi}_{2}$ particle, isolating the initial $\delta-\mathrm{Al}_{3} \mathrm{FeSi}_{2}$ phase from further contacting liquid; and (ii) the peritectic transformation, during which the $\beta-\mathrm{Al}_{5} \mathrm{FeSi}$ envelope thickens by solid state diffusion of alloying elements from $\delta$ $\mathrm{Al}_{3} \mathrm{FeSi}_{2}$ and liquid phases through the peritectic $\beta-\mathrm{Al}_{5} \mathrm{FeSi}$ envelope. It has been reported that both the $\delta-\mathrm{Al}_{3} \mathrm{FeSi}_{2}$ and $\beta-\mathrm{Al}_{5} \mathrm{FeSi}$ particles exhibit similar platelet-like characteristic crystal shapes, but the platelets of $\delta-\mathrm{Al}_{3} \mathrm{FeSi}_{2}$ are generally more blocky [53]. Hence if the transformation from $\delta-\mathrm{Al}_{3} \mathrm{FeSi}_{2}$ into $\beta-\mathrm{Al}_{5} \mathrm{FeSi}$ goes to completion, only relatively thin platelet-like $\beta-\mathrm{Al}_{5} \mathrm{FeSi}$ particles will appear in the as-solidified microstructure. However, if the transformation is only partially complete, both $\delta-\mathrm{Al}_{3} \mathrm{FeSi}_{2}$ and $\beta-\mathrm{Al}_{5} \mathrm{FeSi}$ will be present as complex particles exhibiting an intermediary blocky-to-platelet morphology in which $\beta$ $\mathrm{Al}_{5} \mathrm{FeSi}$ envelopes $\delta-\mathrm{Al}_{3} \mathrm{FeSi}_{2}$. In general, under most cooling conditions during solidification, only fine $\delta-\mathrm{Al}_{3} \mathrm{FeSi}_{2}$ particles are expected to undergo complete transformation into $\beta-\mathrm{Al}_{5} \mathrm{FeSi}$ as the transformation is slow due to solid state diffusion.

In the ingot sample solidified without USMT, the primary Fe-containing intermetallics exhibited long platelet-like shapes (Fig. 5 (a)) in the melt surface (Zone I) and blocky shapes (Fig. 5 (c, d)) in the wall regions (Zones III and IV). They both formed as 
complex particles of $\delta-\mathrm{Al}_{3} \mathrm{FeSi}_{2} / \beta-\mathrm{Al}_{5} \mathrm{FeSi}$. However, the blocky particles contained a significantly larger $\delta-\mathrm{Al}_{3} \mathrm{FeSi}_{2}$ particle than those in the melt surface region. We propose that this is due to different degrees of transformation of $\delta-\mathrm{Al}_{3} \mathrm{FeSi}_{2}$ into $\beta-\mathrm{Al}_{5} \mathrm{FeSi}$. Fig. 8 (a) shows that the average equivalent size of the primary Fe-containing intermetallic particles formed near the mould wall regions are almost twice as large as those formed near the melt surface regions. The diffusion-controlled rate of transformation from $\delta-\mathrm{Al}_{3} \mathrm{FeSi}_{2}$ to $\beta-\mathrm{Al}_{5} \mathrm{FeSi}$ can be assumed to be similar at the same temperature. Therefore the less complete transformation of $\delta-\mathrm{Al}_{3} \mathrm{FeSi}_{2}$ into $\beta-\mathrm{Al}_{5} \mathrm{FeSi}$ platelets observed at the mould wall regions versus that at the melt surface can be attributed to the existence of coarser particles of $\delta$ $\mathrm{Al}_{3} \mathrm{FeSi}_{2}$ for which longer time is required to complete the peritectic transformation.

After USMT, most primary Fe-containing intermetallics exist as single-phase $\beta$ $\mathrm{Al}_{5} \mathrm{FeSi}$ short rod particles (Fig. 10 (d-e)) with a few $\delta-\mathrm{Al}_{3} \mathrm{FeSi}_{2} / \beta-\mathrm{Al}_{5} \mathrm{FeSi}$ complex particles containing a small central area of primary $\delta-\mathrm{Al}_{3} \mathrm{FeSi}_{2}$ (Fig. 10 (f)). USMT has clearly resulted in complete peritectic transformation of most primary $\delta-\mathrm{Al}_{3} \mathrm{FeSi}_{2}$ particles into peritectic $\beta$ $\mathrm{Al}_{5} \mathrm{FeSi}$. As shown schematically in Fig. 12, the finer sized primary $\delta-\mathrm{Al}_{3} \mathrm{SiFe}_{2}$ particles will shorten the time needed to complete the peritectic transformation. USMT produced much finer $\delta-\mathrm{Al}_{3} \mathrm{SiFe}_{2}$ particles thus reducing the time needed to achieve complete transformation to $\beta-\mathrm{Al}_{5} \mathrm{FeSi}$. In addition, USMT may have further enhanced the peritectic transformation by accelerating the peritectic transformation rate, in which case the thickness of the peritectic envelope $\Delta \beta-\mathrm{Al}_{5} \mathrm{FeSi}$ in the alloy after USMT would be greater than that in the case without USMT. Previous studies [32-34] have suggested that the peritectic transformation rate increases markedly under USMT, possible due to two mechanisms: (1) acceleration of the liquid-peritectic phase interfacial diffusion due to cavitation and accompanied mixing of the melt; and, (2) increase in the peritectic reaction temperature according to the Clapeyron equation [54], and thus diffusion is expected to increase with temperature. To clarify this point, the $\beta-\mathrm{Al}_{5} \mathrm{FeSi}$ envelope thicknesses were measured for at least 40 particles in both alloys, and the results are shown in Table IV. An average envelope thickness of $24.6 \mu \mathrm{m}$ was achieved without USMT, as opposed to $26.4 \mu \mathrm{m}$ with USMT. The very similar values indicate that the rate of peritectic transformation $\delta-\mathrm{Al}_{3} \mathrm{FeSi}_{2} \rightarrow \beta-\mathrm{Al}_{5} \mathrm{FeSi}$ remained essentially the same in both alloys. This is not totally unexpected since USMT ceased prior to the peritectic reaction as shown in Fig. 3(b). Consequently, the observations of ultrasound enhancing the peritectic transformation are mainly due to the reduced size of the primary $\delta$ $\mathrm{Al}_{3} \mathrm{FeSi}_{2}$ particles which require much less time to complete transformation than larger primary $\delta-\mathrm{Al}_{3} \mathrm{FeSi}_{2}$ phase particles. 


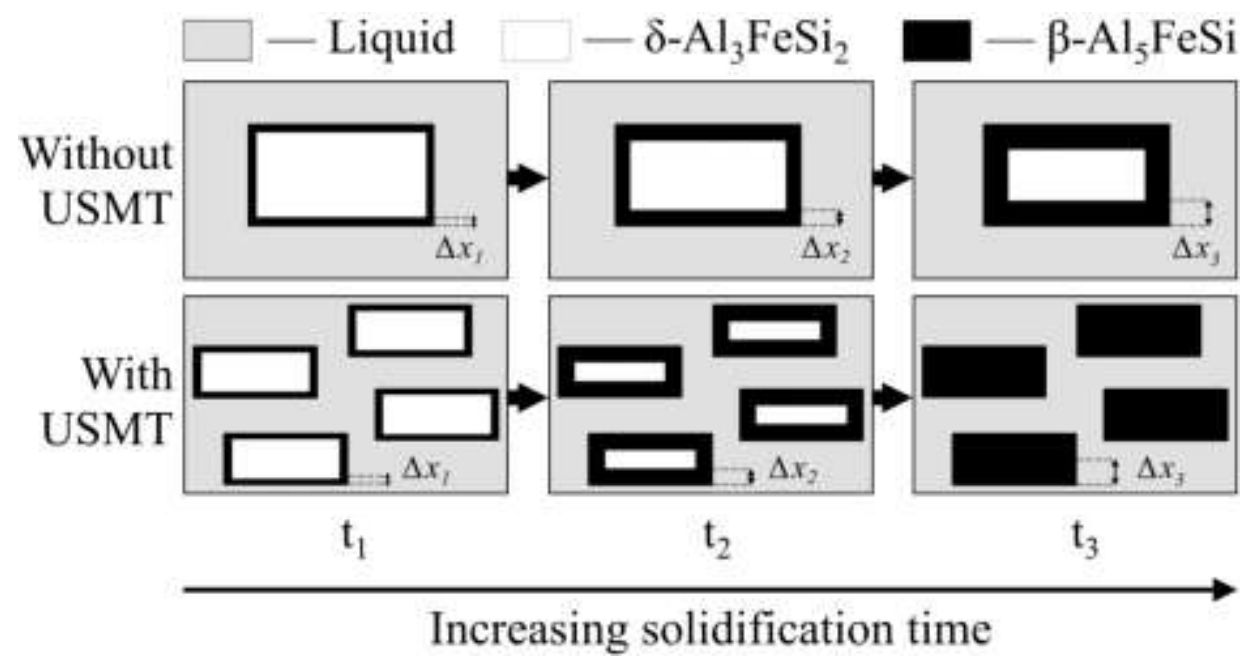

Fig. 12-Schematic diagram showing the effect of USMT on the peritectic transformation $\delta$ $\mathrm{Al}_{3} \mathrm{SiFe}_{2} \rightarrow \beta-\mathrm{Al}_{5} \mathrm{FeSi}$. The finer primary $\delta-\mathrm{Al}_{3} \mathrm{SiFe}_{2}$ particles produced as a result of USMT ensures their complete transformation into peritectic $\beta-\mathrm{Al}_{5} \mathrm{FeSi}$ phase.

\section{Conclusions}

1. In the absence of ultrasonic melt treatment (USMT) severe macro-segregation was observed in the ingot with a noticeably non-uniform distribution of primary Fe-containing intermetallic and primary Si particles, whereas a near homogeneous distribution of both primary phase particles throughout the ingot was produced after USMT, i.e., reduced macro-segregation.

2. Macro-segregation was further quantified using microstructural metallography at different regions of the ingot samples. The results showed that the area fraction, number density, and size distribution of both the primary Fe-containing intermetallic and primary $\mathrm{Si}$ particles became essentially uniform across the ingot after USMT confirming the beneficial effect of USMT on eliminating macro-segregation.

3. USMT had a significant impact on the constitution of the primary Fe-containing intermetallics, where complex particles of $\delta-\mathrm{Al}_{3} \mathrm{FeSi}_{2} / \beta-\mathrm{Al}_{5} \mathrm{FeSi}$ were prominent without USMT while few $\delta$ - $\mathrm{Al}_{3} \mathrm{FeSi}_{2}$ particles were observed after USMT and the primary $\mathrm{Fe}$ containing intermetallics existed mostly as the single-phase $\beta-\mathrm{Al}_{5} \mathrm{FeSi}$.

4. USMT leads to enhanced peritectic transformation $\delta-\mathrm{Al}_{3} \mathrm{FeSi}_{2} \rightarrow \beta-\mathrm{Al}_{5} \mathrm{FeSi}$ due to the significant reduction in the average size of the primary $\delta-\mathrm{Al}_{3} \mathrm{FeSi}_{2}$ particles.

\section{Acknowledgements}


The project was funded by the Australian Research Council (ARC) through DP140100702. Collaboration through the ExoMet Project co-funded by the European Commission's $7^{\text {th }}$ Framework Programme (contract FP7-NMP3-LA-2012-280421), by the European Space Agency and by the individual partner organisations, is acknowledged. We also express our appreciation to Mr. G. Savage, Mr. A. Yob, Mr. J. Read, Mr. D. Graham and Mr. S. Djordjevic for their assistance with experimental work. We acknowledge the facilities, and the scientific and technical assistance, of the Australian Microscopy \& Microanalysis Research Facility at RMIT University.

\section{References}

1. J. Zhou, J. Duszczyk and B. M. Korevaar: J. Mater. Sci., 1991, vol. 26, pp. 3041-50.

2. T.S. Kim, C. Suryanarayana and B.S. Chun: Mater. Sci. Eng. A, 2000, vol. 278, pp. 113-20.

3. L. Wang, M. Makhlouf and D. Apelian: Int. Mater. Rev., 1995, vol. 40, pp. 221-38.

4. $\quad$ N. Tenekedjiev, D. Argo and J. E. Gruzleski: AFS Trans., 1989, vol. 97, pp. 127-36.

5. M. Rajabi, M. Vahidi, A. Simchi and P. Davami: Mater. Charact., 2009, vol. 60, pp. 1370-81.

6. H. J. Huang, Y. H. Cai, H. Cui, J. F. Huang, J. P. He and J. S. Zhang: Mater. Sci. Eng. A, 2009, vol. 502, pp. 118-25.

7. Q. L. Wang, H. R. Geng, S. Zhang, H. W. Jiang and M. Zuo: Metall. Mater. Trans. A, 2014, vol. 45a, pp. 1621-30.

8. Y. Osawa, S. Takarnori, T. Kimura, K. Minagawa and H. Kakisawa: Mater. Trans., 2007, vol. 48, pp. 2467-75.

9. G. Zhong, S. S. Wu, H. W. Jiang and P. An: J. Alloy. Compd., 2010, vol. 492, pp. 482-87.

10. M. Sha, S. S. Wu and L. Wan: Mater. Sci. Eng. A, 2012, vol. 554, pp. 142-48.

11. C. Lin, S. S. Wu, S. L. Lu and P. An: J. Alloy. Compd., 2013, vol. 568, pp. 42-48.

12. C. Lin, S. S. Wu, S. L. Lu, P. An and L. Wan: Intermetallics, 2013, vol. 32, pp. 17683.

13. W. Khalifa, S. El-Hadad and Y. Tsunekawa: Metall. Mater. Trans. A, 2013, vol. 44a, pp. 5817-24.

14. L. F. Mondolfo: Aluminum Alloys: Structure and Properties, Butterworths, London, 1976.

15. W. Khalifa, F. H. Samuel and J. E. Gruzleski: Metall. Mater. Trans. A, 2003, vol. 34a, pp. 807-25.

16. M. H. Mulazimoglu, A. Zaluska, J. E. Gruzleski and F. Paray: Metall. Mater. Trans. A, 1996, vol. 27, pp. 929-36.

17. G. Sha, K. A. Q. O'Reilly, B. Cantor, J. M. Titchmarsh and R. G. Hamerton: Acta Mater., 2003, vol. 51, pp. 1883-97.

18. O. V. Abramov: Ultrasound in liquid and solid metals, CRC Press, Boca Raton, FL, 1994.

19. G. I. Eskin and D. G. Eskin: Ultrasonic Treatment of Light Alloy Melts, 2nd ed., CRC Press, Boca Raton, FL, 2014.

20. A. Ramirez, M. Qian, B. Davis, T. Wilks and D. H. StJohn: Scripta Mater., 2008, vol. 59, pp. 19-22. 
21. M. Qian, A. Ramirez and A. Das: J. Cryst. Growth, 2009, vol. 311, pp. 3708-15.

22. M. Qian, A. Ramirez, A. Das and D. H. StJohn: J. Cryst. Growth, 2010, vol. 312, pp. 2267-72.

23. T. V. Atamanenko, D. G. Eskin, L. Zhang and L. Katgerman: Metall. Mater. Trans. A, 2010, vol. 41a, pp. 2056-66.

24. G. Wang, M. S. Dargusch, M. Qian, D. G. Eskin and D. H. StJohn: J. Cryst. Growth, 2014, vol. 408, pp. 119-24.

25. N. Srivastava, G. P. Chaudhari and M. Qian: J. Mater. Process. Technol., 2017, vol. 249, pp. 367-78.

26. H. R. Kotadia, M. Qian, D. G. Eskin and A. Das: Mater. Design, 2017, vol. 132, pp. 266-74.

27. W. Khalifa, Y. Tsunekawa and M. Okumiya: J. Mater. Process. Technol., 2010, vol. 210, pp. 2178-87.

28. V. O. Abramov, O. V. Abramov, B. B. Straumal and W. Gust: Mater. Design, 1997, vol. 18, pp. 323-26.

29. G. I. Eskin and D. G. Eskin: Ultrason. Sonochem., 2003, vol. 10, pp. 297-301.

30. H. K. Feng, S. R. Yu, Y. L. Li and L. Y. Gong: J. Mater. Process. Technol., 2008, vol. 208 , pp. 330-35.

31. J. B. Ferguson, M. Tabandeh-Khorshid, J. C. Mantas, P. K. Rohatgi, K. Cho and C. S. Kim: Metall. Mater. Trans. B, 2014, vol. 45, pp. 1407-17.

32. W. Zhai and B. B. Wei: Mater. Lett., 2015, vol. 138, pp. 1-4.

33. W. Zhai, Z. Y. Hong, X. L. Wen, D. L. Geng and B. Wei: Mater. Design, 2015, vol. 72, pp. 43-50.

34. R. Chen, D. Zheng, T. Ma, H. Ding, Y. Su, J. Guo and H. Fu: Ultrason. Sonochem., 2017, vol. 38, pp. 120-33.

35. H. R. Kotadia, A. Das, E. Doernberg and R. Schmid-Fetzer: Mater. Chem. Phys., 2011, vol. 131, pp. 241-49.

36. W. Zhai, H. M. Liu and B. Wei: Mater. Lett., 2015, vol. 141, pp. 221-24.

37. E. A. Brandes and G. B. Brook: Smithells Metals Reference Book, 7th ed., Butterworth-Heinemann, Oxford, 1992.

38. N. M. Keita and S. Steinemann: J. Phys. C: Solid State Phys., 1978, vol. 11, pp. 463541.

39. W. Cao, S. L. Chen, F. Zhang, K. Wu, Y. Yang, Y. A. Chang, R. Schmid-Fetzer and W. A. Oates: CALPHAD: Comput. Coupling Phase Diagrams Thermochem., 2009, vol. 33, pp. 328-42.

40. L. Backerud, G. Chai and J. Tamminen: Solidification Characteristics of Aluminium Alloys, Vol. 2: Foundry Alloys, AFS/Skanaluminium, Des Plaines, IL, 1990.

41. A. G. C. Gwyer and H. W. L. Phillips: J. Inst. Met., 1927, vol. 38, pp. 29-83.

42. N. Krendelsberger, F. Weitzer and J. C. Schuster: Metall. Mater. Trans. A, 2007, vol. 38a, pp. 1681-91.

43. D. Liang, Y. Bayraktar, S. A. Moir, M. Barkhudarov and H. Jones: Scripta Metall. Mater., 1994, vol. 31, pp. 363-67.

44. X. Cao, N. Saunders and J. Campbell: J. Mater. Sci., 2004, vol. 39, pp. 2303-14.

45. F. Wang, D. Eskin, J. W. Mi, T. Connolley, J. Lindsay and M. Mounib: Acta Mater., 2016, vol. 116, pp. 354-63.

46. H. W. Kerr, J. Cisse and G. F. Bolling: Acta Metall., 1974, vol. 22, pp. 677-86.

47. A. P. Titchener and J. A. Spittle: Met. Sci., 1974, vol. 8, pp. 112-16.

48. D. H. StJohn and L. M. Hogan: Acta Metall., 1977, vol. 25, pp. 77-81.

49. M. Hillert, In The Metals Society, (London, 1979), pp 81-87.

50. H. Fredriksson and T. Nylen: Met. Sci., 1982, vol. 16, pp. 283-94. 
534 51. D. H. StJohn and L. M. Hogan: Acta Metall., 1987, vol. 35, pp. 171-74.

535 52. D. H. StJohn: Acta Metall. Mater., 1990, vol. 38, pp. 631-36.

536 53. G. Phragmen: J. Inst. Met., 1950, vol. 77, pp. 489-551.

537 54. J. D. Hunt: J. Appl. Phys., 1966, vol. 37, pp. 254-57. 


\section{Figure caption list}

540 Fig. 1-Schematic illustration of the experimental set-up.

541

542 Fig. 2-Temperature $v s$ fraction solid curve as predicted by PANDAT $^{\mathrm{TM}}$ assuming 543 equilibrium solidification of the Al-19Si-4Fe alloy.

545 Fig. 3-Cooling curves and their first derivatives for the Al-19Si-4Fe alloy: (a) without $546 \quad$ USMT and (b) with USMT.

547 Fig. 4-(a) Vertical section of a solidified Al-19Si-4Fe ingot without USMT and (b) the same alloy with USMT. Note the distinct difference in macro-segregation and phase distribution in (a) and (b).

550

551

Fig. 5-SEM BSE micrographs showing the typical primary phase structures in the four different zones of the Al-19Si-4Fe ingots shown in Fig. 4.

Fig. 6-Area fraction of primary phases without and with USMT in the ingot samples shown in Fig. 4: (a) primary Fe-containing intermetallics, and (b) primary Si. Refer to Fig. 4 for the different zones.

557

Fig. 7-Number density of primary phases without and with USMT for the ingot samples shown in Fig. 4: (a) primary Fe-containing intermetallics, and (b) primary Si. Refer to Fig. 4 for the different zones.

561

562 Fig. 8-Morphological parameters of primary phases for the alloy ingots shown in Fig. 4: (a) primary Fe-containing intermetallics without USMT; (b) primary Fe-containing intermetallics with USMT; (c) primary Si without USMT; and (d) primary Si with USMT. Refer to Fig. 4 for the different zones.

Fig. 9-(a) Typical BSE image showing unreacted platelet-like Fe-containing intermetallics existing as complex particles of $\delta-\mathrm{Al}_{3} \mathrm{FeSi}_{2} / \beta-\mathrm{Al}_{5} \mathrm{FeSi}$ in Zone I of the ingot sample solidified without USMT, and (b) an enlarged view. 
571 Fig. 10 — BSE images showing examples of primary Fe-containing intermetallic particles: (a572 c) complex blocky particles of $\delta-\mathrm{Al}_{3} \mathrm{FeSi}_{2} / \beta-\mathrm{Al}_{5} \mathrm{FeSi}$ observed near the mould wall regions of 573 the ingot samples solidified without USMT; (d, e) single-phase short intermetallic particles 574 observed in the ingot after USMT; and (f) a complex particle of $\delta-\mathrm{Al}_{3} \mathrm{FeSi}_{2} / \beta-\mathrm{Al}_{5} \mathrm{FeSi}$ 575 observed in the ingot sample with USMT.

577 Fig. 11-EDS line scans across selected Fe-containing intermetallics particles: (a) the 578 complex particle in Fig. 9 (c); (b) the complex particle in Fig. 9 (f); and (c) the single-phase $579 \beta-\mathrm{Al}_{5} \mathrm{FeSi}$ particle in Fig. 9 (e).

580

581 Fig. 12-Schematic diagram showing the effect of USMT on the peritectic transformation $\delta$ $582 \mathrm{Al}_{3} \mathrm{SiFe}_{2} \rightarrow \beta-\mathrm{Al}_{5} \mathrm{FeSi}$. The finer primary $\delta-\mathrm{Al}_{3} \mathrm{SiFe}_{2}$ particles produced as a result of USMT 583 ensures their complete transformation into peritectic $\beta-\mathrm{Al}_{5} \mathrm{FeSi}$ phase. 
588 for not specified.

\begin{tabular}{|c|c|c|c|c|c|c|c|c|c|c|c|c|c|c|c|}
\hline \multirow{2}{*}{$\begin{array}{l}\mathrm{Si}, \mathrm{Fe} \\
\text { content } \\
\text { (pct) }\end{array}$} & \multirow{2}{*}{$\begin{array}{c}\text { Neutralising } \\
\text { elements } \\
\text { (pct) }\end{array}$} & \multirow{2}{*}{$\begin{array}{l}\text { Primary } \\
\text { phase }\end{array}$} & \multirow{2}{*}{$\begin{array}{l}\text { Macro- } \\
\text { segregation } \\
\text { reported }\end{array}$} & \multicolumn{2}{|c|}{$\begin{array}{l}\text { Influence on peritectic } \\
\text { solidification }\end{array}$} & \multirow{2}{*}{$\begin{array}{c}\text { Horn } \\
\text { material }\end{array}$} & \multirow{2}{*}{$\begin{array}{c}\text { Horn } \\
\text { diameter } \\
(\mathrm{mm})\end{array}$} & \multirow{2}{*}{$\begin{array}{c}\text { Applied } \\
\text { power } \\
\text { (W) }\end{array}$} & \multirow{2}{*}{$\begin{array}{c}\text { Amplitude } \\
(\mu \mathrm{m})\end{array}$} & \multirow{2}{*}{$\begin{array}{c}\text { Frequency } \\
\qquad(\mathrm{kHz})\end{array}$} & \multirow{2}{*}{$\begin{array}{l}\text { Horn temp. } \\
\qquad(\mathrm{K})\end{array}$} & \multirow{2}{*}{$\begin{array}{l}\text { Horn } \\
\text { immersion } \\
\text { depth } \\
(\mathrm{mm})\end{array}$} & \multirow{2}{*}{$\begin{array}{l}\text { Melt } \\
\text { size } \\
(\mathrm{g})\end{array}$} & \multirow{2}{*}{$\begin{array}{c}\text { Difference } \\
\text { in pouring } \\
\text { temp.* } \\
(\mathrm{K})\end{array}$} & \multirow[t]{2}{*}{ Ref. } \\
\hline & & & & Suppression & Promotion & & & & & & & & & & \\
\hline $17,1.3$ & $\mathrm{Mn}=0.5$ & $\mathrm{Si}$ & No & \multicolumn{2}{|c|}{ Phases not characterised } & $\begin{array}{c}\text { Stainless } \\
\text { steel }\end{array}$ & $\begin{array}{l}\text { Crucible } \\
\text {-type }\end{array}$ & 2000 & $25-30$ & 19.5 & Room temp. & N/A & 1300 & $\begin{array}{c}\text { No } \\
\text { difference }\end{array}$ & [13] \\
\hline 17,2 & $\mathrm{Mn}=0.8$ & $\mathrm{Si}$ & No & \multicolumn{2}{|c|}{ No effect } & $\mathrm{Ti}$ & $N S$ & 1600 & $N S$ & 20 & $N S$ & $15-20$ & 600 & 85 to 125 & [11] \\
\hline 17,2 & $\begin{array}{c}\mathrm{Mn}=0.4 \\
0.8\end{array}$ & $\mathrm{Si}$ & No & $\beta$-phase & $\delta$-phase & $\mathrm{Ti}$ & $N S$ & 1600 & $N S$ & 20 & $N S$ & $15-20$ & 600 & 110 & [12] \\
\hline 18,4 & None & $\delta$-phase & No & \multicolumn{2}{|c|}{ No effect } & Sialon & 20 & 1200 & 20 & 19 & $N S$ & 10 & 240 & $\begin{array}{c}\text { Not } \\
\text { poured }\end{array}$ & [8] \\
\hline $20,0.7$ & $\begin{array}{c}\mathrm{Co}=0 \text { to } \\
1.5\end{array}$ & $\mathrm{Si}$ & No & \multicolumn{2}{|c|}{ No effect } & $\mathrm{Ti}$ & $N S$ & 1200 & $N S$ & 20 & $N S$ & $15-20$ & 600 & 135 & [10] \\
\hline 20,2 & $\begin{array}{c}\mathrm{Mn}=0.0 \\
0.5\end{array}$ & $\mathrm{Si}$ & No & $\beta$-phase & $\delta$-phase & $\mathrm{Ti}$ & $N S$ & 1200 & $N S$ & 20 & $N S$ & $15-20$ & 600 & 130 & [9] \\
\hline
\end{tabular}

589 Note: The difference in pouring temperature refers to the difference in pouring temperature used without and with USMT. 
590 Table II. Solidification reactions observed from the cooling curves of the Al-19Si-4Fe 591 alloy without and with USMT.

\begin{tabular}{|c|c|c|c|}
\hline $\begin{array}{c}\text { Reaction } \\
\text { number }\end{array}$ & Type of reaction & \multicolumn{2}{|c|}{ Estimated temperature, K $\left({ }^{\circ} \mathbf{C}\right)$} \\
\hline & & Without USMT & With USMT \\
\hline$(1)$ & $\mathrm{L} \rightarrow \delta-\mathrm{Al}_{3} \mathrm{FeSi}_{2}$ & $938(665)$ & $*$ \\
\hline$(2)$ & $\mathrm{L} \rightarrow \delta-\mathrm{Al}_{3} \mathrm{FeSi}_{2}+\mathrm{Si}$ & $936(663)$ & $*$ \\
\hline$(3)$ & $\mathrm{L}+\delta-\mathrm{Al}_{3} \mathrm{FeSi} i_{2} \rightarrow \beta-\mathrm{Al}_{5} \mathrm{FeSi}+$ & $868(595)$ & $868(595)$ \\
\hline $\mathrm{Si}^{(4)}$ & $\mathrm{L} \rightarrow \alpha-\mathrm{Al}+\mathrm{Si}+\beta-\mathrm{Al}_{5} \mathrm{FeSi}$ & $849(576)$ & $849(576)$ \\
\hline
\end{tabular}

*Difficult to determine from the experimental data (see text). 
594 Table III. EDS point analysis results of primary Fe-containing intermetallic particles.

\begin{tabular}{|c|c|c|c|c|c|c|c|}
\hline \multirow[b]{2}{*}{ Alloy } & \multirow{2}{*}{\multicolumn{2}{|c|}{ Structure }} & \multicolumn{5}{|c|}{ Composition (at. pct) } \\
\hline & & & \multirow{2}{*}{$\begin{array}{c}\text { Al } \\
50.92 \pm \\
3.28\end{array}$} & \multirow{2}{*}{$\begin{array}{c}\text { Fe } \\
18.03 \pm \\
3.11\end{array}$} & \multirow{2}{*}{$\begin{array}{c}\mathbf{S i} \\
31.05 \pm \\
0.84\end{array}$} & \multirow{2}{*}{$\begin{array}{c}\text { Fe:Si } \\
0.58 \pm \\
0.07\end{array}$} & \multirow{2}{*}{$\begin{array}{c}\text { Probable } \\
\text { Phase }\end{array}$} \\
\hline Without & Complex & Central & & & & & \\
\hline USMT & particles & Outer & $\begin{array}{c}65.89 \pm \\
0.77\end{array}$ & $\begin{array}{c}16.47 \pm \\
0.88\end{array}$ & $\begin{array}{c}17.64 \pm \\
0.93\end{array}$ & $\begin{array}{c}0.92 \pm \\
0.10\end{array}$ & $\beta-\mathrm{Al}_{5} \mathrm{FeSi}$ \\
\hline \multirow{3}{*}{$\begin{array}{l}\text { With } \\
\text { USMT }\end{array}$} & $\begin{array}{c}\text { Single- } \\
\text { phase } \\
\text { particles }\end{array}$ & - & $\begin{array}{c}65.94 \pm \\
0.77\end{array}$ & $\begin{array}{c}16.3 \pm \\
0.67\end{array}$ & $\begin{array}{c}17.76 \pm \\
0.57\end{array}$ & $\begin{array}{c}0.92 \pm \\
0.05\end{array}$ & $\beta-\mathrm{Al}_{5} \mathrm{FeSi}$ \\
\hline & \multirow{2}{*}{$\begin{array}{l}\text { Complex } \\
\text { particles }\end{array}$} & Central & $\begin{array}{c}50.97 \pm \\
4.62\end{array}$ & $\begin{array}{c}18.19 \pm \\
4.06\end{array}$ & $\begin{array}{c}30.85 \pm \\
0.83\end{array}$ & $\begin{array}{c}0.59 \pm \\
0.09\end{array}$ & $\delta-\mathrm{Al}_{3} \mathrm{FeSi}_{2}$ \\
\hline & & Outer & $\begin{array}{c}65.96 \pm \\
1.17\end{array}$ & $\begin{array}{c}16.53 \pm \\
0.92\end{array}$ & $\begin{array}{c}17.5 \pm \\
0.87\end{array}$ & $\begin{array}{c}0.94 \pm \\
0.10\end{array}$ & $\beta-\mathrm{Al}_{5} \mathrm{FeSi}$ \\
\hline
\end{tabular}


596 Table IV. The average intermetallic half-width (critical diffusion length) and the average 597 thickness of the peritectic $\beta-\mathrm{Al}_{5} \mathrm{FeSi}$ phase envelope in the alloy without and with USMT.

\begin{tabular}{|c|c|c|}
\hline Alloy & $\begin{array}{c}\text { Half-width of the particle, } \\
\boldsymbol{\mu m}\end{array}$ & $\begin{array}{c}\text { Thickness of the peritectic } \\
\text { envelope, } \boldsymbol{\mu m}\end{array}$ \\
\hline Without USMT & $61.6 \pm 20.7$ & $24.6 \pm 15.4$ \\
\hline With USMT & $27.7 \pm 6.9$ & $26.4 \pm 5.7$ \\
\hline 598
\end{tabular}

599 